\title{
THE SURFACE CHARACTER OF Staphylococcus aureus ISOLATED FROM SUBCLINICAL MASTITIS OF DAIRY COW SUPPORTING ADHERENCE TO UDDER EPITHELIAL CELL
}

\author{
A.E.T.H. Wahyuni ${ }^{1}$, D. Winarso ${ }^{2}$, V. Valenti ${ }^{3}$ and Franky ${ }^{3}$ \\ ${ }^{1}$ Faculty of Veterinary Medicine of Gadjah Mada University, \\ ${ }^{2}$ Veterinary Medicine Program of Brawijaya University \\ ${ }^{3}$ Student of Veterinary Medicine Faculty of Gadjah Mada University. \\ Corresponding E-mail: wahyuni_aeth@yahoo.com \\ Received April 2010; Accepted August 23, 2010
}

\begin{abstract}
Staphylococcus aureus (S. aureus) is one among pathogen bacteria that caused mastitis in dairy cow in Indonesia. Its ability to initiate infection depends on the surface character of the bacteria. The surface character of $S$. aureus is determined by the corelation of red blood cell hemagglutination activity, hydrophobicity, production of protein A, and bacterial adherence to the mammary epithelial cells of the host. This research was designed to characterize the surface of S.aureus, which correlates to bacterial adherence. Four isolates of $S$. aureus were taken from subclinical mastitis milk of dairy farm in Malang, East Java. The surface character of S.aureus was determined by performing the red blood cell hemagglutination test using the dairy cow erythrocyte suspension with concentration of $0.5 \%, 1 \%$, and 2\%. The hydrophobicity expression was determined by Salt Aggregation Test (SAT) method using the Ammonium Sulfate suspension with concentration of $1.2 \mathrm{M}, 1.6 \mathrm{M}, 2.0 \mathrm{M}, 2.4 \mathrm{M}$, and 3.2 M. Serum soft agar (SSA) test was used to indicate the production of protein A; Ability of adhesion was done by adhering the S.aureus, which were already labelled by Fluorescent Ichtiocyanate (FITC) to the mammary epithelial cell of post-calving mice. Result of this this research showed that the surface characters of S.aureus, which correlates to the adherence, comprise of erythrocytes hemagglutination ability, hydrophobicity, and protein A production. Isolates of S.aureus, which is hydrophobic, possess haemagglutinine, and protein A were able to adhere to mammary epithelial cell with higher quantity

Keywords: adherence, Staphylococcus aureus, surface character
\end{abstract}

\section{INTRODUCTION}

Until now, the most important infectious disease to countless number of dairy cow is mastitis (Edmondson and Bramley, 2004). Characters of subclinical mastitis are the increase of the number of somatic cell in the milk, physical changes, as well as milk composition, and with or without accompanying pathological changes in the gland itself (Subronto, 2003; Edmondson and Bramley, 2004). In Indonesia the incidence of subclinical mastitis in dairy cows is very high (9598\%) and caused many losses (Sudarwanto, 1999).

According to Zarzosa et al. (2007), Staphylococcus aureus is a most frequently isolated pathogenic bacteria which cause clinical or subclinical mastitis in worldwide distribution. Freter and Jones (1983), Smith (1984) stated that bacterial pathogenicity was determined by the ability of bacteria to adhere the mucosal surface which was correlated to the surface structure of bacteria and host factors. Pelczar and Chan (2006) stated that the virulence of bacteria was also influenced by presence of capsule. Capsulated bacteria would be more virulent since the ability of polysacharide capsule to prevent phagocytosis or ingestion by the host phagocytic cells. Lowy (1998) also stated that most strains of Staphylococcus produced the microcapsule. Furthermore, most of the S.aureus isolated from cow mammary glands had polysacharide located on the outer layer of its peptidoglycan layer. That component enhances the bacteria adhesion ability to the epithelial cell.

Agglutinine is the antibody factors that perform the agglutination process. Wahyuni (1998) stated that the adhesion ability of Streptococcus agalactiae to mammary epithelial cells of dairy cows was highly influenced by their 
hemaglutinine. Research of Wahyuni et al. (2005) showed that hemaglutinine was suspected as an important virulent factor (as adhesine). Separation step of hemagglutinin of S.aureus with Sodium Dodecyl Sulphate-Polyacrilamide Gel Electrophoresis (SDS-PAGE) that hemaglutinine only had one protein band with molecular weight of 27 $\mathrm{kDa}$ (Wahyuni et al., 2005). The bacterial infection is usually iniatiated from the nipple then moving deeper to the lactiferous ducts and finally reaches sisterna. Infection process is suspected to be initiated by the attainment of bacteria to penetrate the chitin layer of nipple and is prolonged with the adhesion and colonization of bacteria to the epithelial cell of mammary gland. These steps are considered as a critical step to accomplish the infection (Wibawan et al., 2005).

Result of research performed by Teranishi $e t$ al (1998) cited by Suarsana (2002) indicated that potein-A positive strain of Staphylococcus $s p$. attached to the vero cell in higher number compared to negative protein-A strain. S.aureus synthesized a few of surface factors associated with the host tissues (such as collagen and fibrinogen-binding protein) and protective factors against the host defense system.

Hydrophobic character of the bacteria also holds a role on its ability to adhere the host cells. Hydrophobic character was highly determined by the amount of surface proteins, comprising of protein A in S.aureus and protein M in S.pyogenes (Miorner et al., 1982). As stated by Wibawan et al. (2005) that surface protein antigen Staphylococcus aureus was protein A and fibronectin-binding proteins that play a role in high hydrophobicity strains of Staphylococcus aureus from positive SAT.

According to Freter and Jones (1983); Smith (1984), the adhesion of bacteria on mucosal surfaces were the most important part of bacterial pathogenicity.

This research was designed to characterize the surface of S.aureus, which correlates to bacterial adherence.

\section{MATERIAL AND METHODS}

Instruments used in this research comprised of sterile reaction tubes, sterile small tube, sterile centrifuge tubes, usa, spirit lamp, glass objects, micropipet, microtipe, microplate, hemositometer, vortex mixer, centrifuge, syringes, needles, sterile toothpick, surgical instruments, spatulas, incubators, cupboard ice, light microscope, and microscope fluorescent

The materials used in this research were 4 isolates of Staphylococcus aureus isolated from subclinical mastitis milk from Malang (3 isolates was from KUD Jabung in Sidomulyo village, 1 isolate was from the Koperasi Sae in Pujon district-Malang regency), Phosphate Buffer Saline (PBS), Carbolic Gentian Violet Solution, Lugol solution, Solution of $95 \%$ alcohol, Fuchsine Solution, Hydrogen Peroxide (H2O2) 3\%, rabbit plasma, Solution of Barium Sulfate (BaSO4) estimate of $24 \times 108$ bacterial cells / ml (Mc Farland Standard number 8 ) to equate the amount of bacteria suspension, cow erythrocytes with the concentration of $0.5 \%, 1 \%, 2 \%$, ammonium sulphate with a concentration $1.2 \mathrm{M} ; 1.6 \mathrm{M}, 2.0$ $\mathrm{M} ; 2.4 \mathrm{M}$ and $3.2 \mathrm{M}$, mammary gland epithelial cells from post calving mouse, fluorescein isothiocyanate (FITC), and Minimum Essential Medium (MEM). Medium was used to culture the bacteria is Brain Heart Infusion (BHI), Sheep Blood Agar Base plate, Manitol Salt Agar (MSA), and warm Soft Agar (SA), and rabbit serum.

\section{Reidentification and characterization}

Reidentification S.aureus was performed by observing the morphology of the colony of the blood agar plate (BAP), Gram staining, catalase test, coagulase test in slide and tube, and manitol fermentation test (Green et al., 2004).

\section{Hemaglutination Test (HA) of Erythrocytes}

Bacteria: S.aureus was cultured in $15 \mathrm{ml}$ of BHI medium, incubated $37^{\circ} \mathrm{C}$ for $18-24$ hours. The culture was then centrifugated at 3000 $\mathrm{rpm} / \mathrm{min}$, then washed with PBS 3 times and synchronized with the concentration of $\mathrm{BaSO} 4$ solution 24x108 (Mc Farland number 8).

Erythrocytes: Blood suspension was taken from dairy cows, mixed with the anticoagulant of ethylenediaminetetraacetic acid (EDTA, Merck). Then, the suspension was centrifugated at 2500 $\mathrm{rpm} / \mathrm{min}$ for 5 minutes and washed for 3 times with the speed of $800 \mathrm{rpm} / \mathrm{min}$ each for 5 minutes. Concentration of erythrocytes was made to $0.5 \%$; $1 \%, 2 \%$ by applying erythrocytes that which allready washed into the tube of Packed Cell Volume (PCV) and centrifugated again for 10-15 minutes.

Slow Hemagglutination: The presence of bacteria hemaglutinine can be determined by hemaglutination (HA) test. HA tests was performed by filling all wells in the microplate with $50 \mu \mathrm{l}$ of PBS, then the first well was filled 
with $50 \mu$ suspension of bacteria which had been synchronized and then mixed by using the diluter until 11th well. The erythrocytes suspension was then filled into all well in the microplate. So at the end, well number 12 will only be filled by PBS and erythrocyte suspension and this well be the standard well to read the result in another well.

Rapid Hemagglutination: Rapid HA test was performed by using $50 \mu \mathrm{l}$ of bacteria suspension mixed with $50 \mu \mathrm{l}$ of erythrocytes in the glass object, stirred using a sterile toothpick, and then observed for the presence of aggregation in the well. Positive reaction was indicated by the prescence of agglutination/prescipitation (Kurl et al., 1989).

\section{Hidrophobicity Test}

Hidrofobicity character of bacteria was determined using the method of aggregation test. $S$. aureus, which has been equated using the solution of $\mathrm{BaSO} 4$, tested by ammonium sulfate solution with each concentration of $1.2 \mathrm{M} ; 1.6 \mathrm{M}$, $2.0 \mathrm{M} ; 2.4 \mathrm{M} ; 3.2 \mathrm{M}$, to determine their surface characteristics respectively. A total of $50 \mu \mathrm{l}$ of bacteria mixed with $50 \mu \mathrm{l}$ solution of ammonium sulphate on the object glass, stirred by a sterile toothpick and observed the occurrence of aggregation. Positive results was indicated by the forming of aggregation like microscopic white sand and negative was indicated by the absence of aggregation (Ljungh et al., 1985).

\section{Detection the presence of protein A using the SSA Test}

The presence of protein A on the surface of $S$. aureus was detected by culturing the isolate into the Serum Agar (SA) and the Serum Soft Agar (SSA). In the SA medium, S. aureus would grow diffusely if the protein A was absent in its surface. While, compact growth of colony indicated the prescence of protein A in the surface of bacteria (Forsum et al., 1972). Culture of $S$. aureus in BHI medium was innoculated into the SA medium dan SSA medium. SSA medium was the SA medium that already mixed with the rabbit using the vortex mixer until the mix was homogen. This mix was then incubated in temperature of $37^{\circ} \mathrm{C}$ for $18-24$ hours. Compact colony growth would be seen in round form while diffuse clolony would be seen in elongated form (Wibawan \& Lämmler 1990).

\section{Adhesion test on rat epithelial cells}

This test used epithelial cells of the mammary gland of rat (Rattus norvegicus) of 21 days after birth. Epithelium was scraped using spatel and suspended in MEM and then made into the concentration of $10^{5}$ by using hemocitometer. According to Mather and Roberts (1998), the calculation of the concentration of epithelial cells used the equation:

$$
\mathbf{c}=\mathbf{n x v}
$$

where:

$\mathrm{c}=$ concentration of epithelial cells per $\mathrm{ml}$;

$\mathrm{n}=$ number of epithelial cells counted in $1 \mathrm{~mm}^{2}$;

$v=$ volume counted $=10^{4}$

Cultures of $S$. aureus bacterial counted by the concentration of $24 \times 108$ (as above). A total of $1 \mathrm{ml}$ of bacterial suspension of each plus FITC (Sigma; $1 \mathrm{mg} / \mathrm{ml}$ ) was incubated at a temperature of $25^{\circ} \mathrm{C}$ for 1 hour. After centrifugated, it was washed by MEM and repeated until 2-3 times. Pellets was supplemented with $1 \mathrm{ml}$ of MEM and $1 \mathrm{ml}$ of suspended with epithelial cells of the rat udder $(105$ cells $/ \mathrm{ml})$, then incubated for 1 hour at $37^{\circ} \mathrm{C}$. Epithelial cells was isolated from the udder of bacteria that were not attached to the speed of $5000 \mathrm{rpm}$ centrifugation for 5 minutes 2-3 times using MEM. Mixture of bacterial cells and epithelial cells in the udder of an object dropped into a glass and covered by a cover slip.

The number of bacteria attached to epithelial cells was calculated by the help of udder fluorescent microscope. The calculation of the number of bacteria was done by counting the number of bacteria attached to each cell from the udder epithelial cells 20 (Wibawan and Lammler, 1992; Wahyuni, 1998 after modified).

\section{RESULTS AND DISCUSSION}

The re-identification of 4 S.aureus isolates performed by observing the surface of the colonies on the Blood Agar Base, the morphology of bacteria cells with Gram staining, result of catalaze test, mannitol fermentation ability and coagulation tests are presented in Table 1.

The erythrocyte agglutination of $S$. aureus was used to differ pathogenic strain subgroup. Result of this test, like complement fixation test and agglutinine absorption test, was limited and was difficult to interpret. Result of erythrocyte agglutination test showed that 2 isolates were positive agglutination and other 2 isolates were negative agglutination. Positive result was determined by examining the agglutination of 
Table 1. Reidentification Result of Staphylococcus aureus

\begin{tabular}{lccccccc}
\hline Location & Code & colony & Gram & Shape & catalaze & MSA & Coagulaze \\
\hline Jabung & B/I & Dry & + & Coccus & + & + & + \\
\hline & H/I & Mukoid & + & Coccus & + & + & - \\
\hline & I/I & Mukoid & + & Coccus & + & + & + \\
\hline Pujon & H/U & Mukoid & + & Coccus & + & + & + \\
\hline
\end{tabular}

erythrocyte when the erythrocyte solution was suspended with the bacteria suspension, marked by the prescence of sand-like aggregates. Meanwhile the negative result was marked by the absence of aggregates and prescipitation in the bottom side. Polysacharide capsule may affect the erythrocyte hemagglutination by the bacteria. The presence of polysacharide capsule could conceal the presence of hemagglutinin, which its position might be below the capsule (Wibawan et al., 2005). The thickness of polysacharide capsule was expressed from the morphology of colonies that grew in BAB plate. Mucoid colony indicated that the bacteria possessed a thick polysacharide capsule while rough colony indicated that bacteria did not possess polysacharide capsule so the bacteria were able to agglutinate the erythrocyte (Wibawan et al., 1999). The hemaglutination test results of S.aureus are presented in Figure 1.

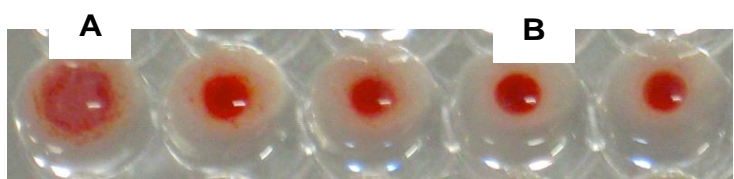

Figure 1. The hemaglutination test of $S$. aureus.

A : HA test positive; B : HA test negative

The character of bacterial surface could be either hydrophobic or hydrophilic and so do with $S$. aureus. Hidrophobicity character could be tested by Salt Agregation Test (SAT) using the physiological salt solution (Han et al. 2000). According to Lehninger (1990), ammonium sulfate could be used to determine the degree of hydrophobicity which showed how strong the bacteria drawing the water molecules and precipitating the protein molecules. In this result only 1 isolate were aggregated by ammonium sulfate started of the concentration of $2.0 \mathrm{M}$. Result of this research supports the opinion that bacterial capsule of both isolates were not perfectly covered all the surface protein of bacteria.

SAT is based on the ability of ammonium sulfate solution to attract the water molecules usually bundled to protein substance. Perfectlyencapsulated bacteria would not be aggregated since its capsule covers the proteins of the cell wall. Bacterial cell surface was made up of carbohydrates and proteins with vaired ratio could determine whether the bacteria were easily aggregated or not by the various concentrations ammonium sulfate. Bacteria with higher amount of protein would be easier aggregated by low concentration of ammonium sulfate, while the higher concentration of carbohydrates was harder for the bacteria to be aggregated by ammonium sulfate (Rozgonyi et al., 1991; Wibawan and Laemmler, 1992). Acccording to Wibawan et al. (2005), positive-SAT isolates will form sand-like particle. Ljungh et al. (1985) stated that extremely-hydrophobic bacteria would be aggregated by phosphate buffer solution with concentration of $0.002 \mathrm{M}$ at $\mathrm{pH}$ of 6.8 .

The prescence of protein A can be tested by SSA test. SSA test is a simple method used for screening the encapsulated Staphylococcus aureus. Positive result of this test was indicated by diffuse growth in the medium which means that the bacteria was encapsulated (Forsum et al., 1972). The results of this study were varied. Isolates of $\mathrm{B} / \mathrm{I}$ an $\mathrm{I} / \mathrm{I}$ showed diffuse growth in $\mathrm{SA}$ medium and compact-diffuse growth in SSA medium. This condition indicated that the cell wall of bacteria possess capsule which didsn't cover cell wall perfectly, therefore some of colonies could express their protein A. Another possibility was that the protein A in the cell wall of bacteria was not equally distributed. Isolate H/I showed diffuse growth in the SA medium and compact growth in SSA medium. This result indicated that this isolate possess protein A was not covered by the capsule. Forsum et al. (1972) stated that compact growth is usually a result from reaction of clumping factor and the reducing production of fibrinogen and also a result from reaction between protein A and the Fc part of IgG. Therefore, the frail activity of fibrinogen in the rabbit serum affect the growth of colonies in SSA 
medium. $\mathrm{H} / \mathrm{U}$ isolate showed the diffuse growth in SA medium and also SSA medium. This indicated that $\mathrm{H} / \mathrm{U}$ isolate probably didn't possess protein A or not quite enough amount of protein A. This is in agreement with the statement of Forsum et al. (1972) about a few strains of S.aureus which possess high amount of protein A but encapsulated will form diffuse colony to the SSA mixed with rabbit serum.

Generally, S.aureus isolated from subclinical mastitis dairy cow would grow diffusely in SSA medium (Wibawan et al., 2005). As added by Han et al. (2000), diffuse colony indicated presence of capsule and becomes a character for so many isolates of Staphylococcus aureus isolated from positive mastitis milk. Forsum et al. (1972) reported that the prescence of capsule may inhibit the reaction between protein A with $\mathrm{IgG}$ because of the reclusiveness of then expression of protein A. High concentration of fibrinogen in normal serum will induce compact colony growth in soft agar medium, while normal concentration of fibrinogen would induce diffuse colony growth. Growth result of S.aureus in the SSA medium was presented on Figure 2. Result of the characterization of S.aureus which correlated to the adhesion ability to epithelial cell of mammary gland is presented on Table 2. Adhesion ability of S.aureus observed using the fluorescence microscope is presented in Figure 3.

According to Wibawan et al. (2005), adhesion of $S$. aureus could be proved by observing the adhesion of positive hemagglutinine bacteria to the mammary gland epithelial cell in the form of small clusters with the amount of 2

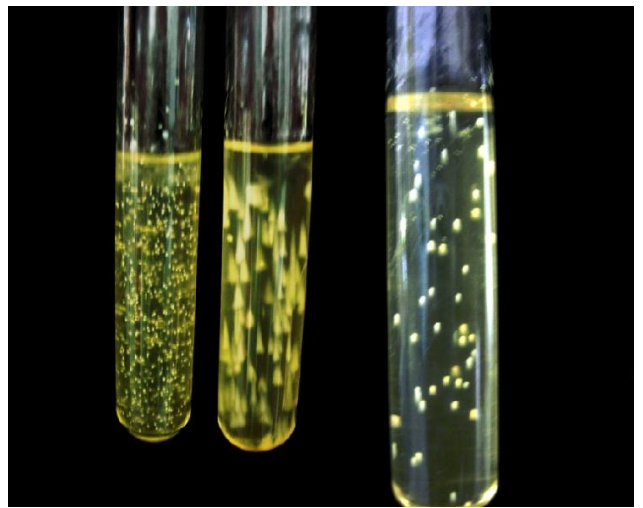

Figure 2. Comparison of colony growth of Staphylococcus aureus that is compact, diffuse, and the compact tail on SSA medium Description:

A.1: compact growth

A.2: diffuse growth

B : compact growth, and there is a diffuse

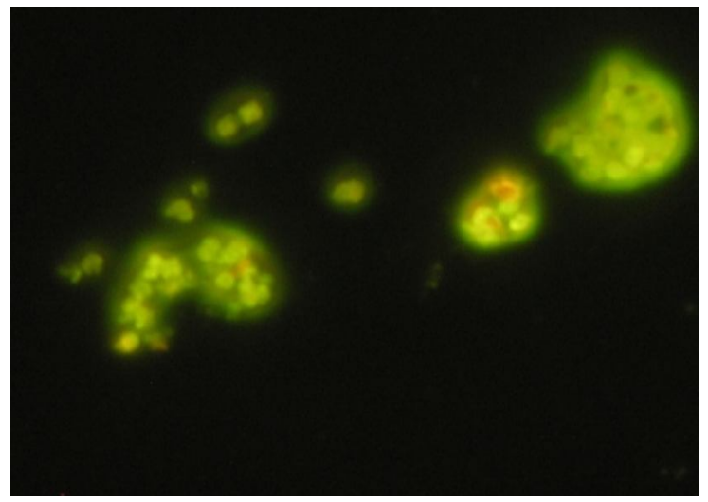

Figure 3. The adhesion of Staphylococcus aureus udder to the rat epithelial cells by staining fluorescent

Table 2. The Characterize Result of Staphylococcus aureus and Adhesi Test for Udder Epithel Cell

\begin{tabular}{cccccccccccc}
\hline Code & \multicolumn{3}{c}{$\begin{array}{c}\text { Hydrophobicity } \\
(\mathrm{M})\end{array}$} & \multicolumn{4}{c}{$\begin{array}{c}\text { Aglutination } \\
\text { Erythrozite }(\%)\end{array}$} & SSA & \multirow{2}{*}{ Adhesion } \\
\hline & 1.2 & 1.6 & 2 & 2.4 & 3.2 & 0.5 & 1 & 2 & & \\
\hline B/I & + & + & + & + & + & + & + & - & C.D & 23.42 \\
\hline H/I & - & - & - & - & - & - & - & - & C & 18.3 \\
\hline I/I & - & - & - & - & - & + & + & - & C.D & 17.65 \\
\hline H/U & - & - & + & + & + & - & - & - & D & 18.72 \\
\hline C.D : Compact-Diffus ; & D: Diffus & & & & & &
\end{tabular}

until 5 cells per mammary glannd epithelial cell. The $\mathrm{B} / \mathrm{I}$ isolate was the most adhesive to mammary epithelial cell. Judging from the character of isolate, this $S$. aureus possess the ability to agglutinate the erythrocyte and also the hydrophobic character. This result is corresponded to the previous research (Wahyuni, 1998; Wahyuni et al., 2005). However, Abrar (2001) 
stated that hemagglutinine of S.aureus didn't have any correlation with the hydrophobicity.

Isolate of $\mathrm{H} / \mathrm{U}$ had higher degree of adhesion compared to $\mathrm{H} / \mathrm{I}$ isolate, but not significant. This condition was probably because of the coagulase enzyme that was not produced by $\mathrm{H} / \mathrm{I}$ isolate. This showed that the isolate of bacteria was not very virulent. This fact is the statement of Teranishi et al (1998), cited by Suarsana (2002) that coagulase negative $S$. aureus was proved to be less virulent than the coagulase positive S.aureus. The isolate of $\mathrm{H} / \mathrm{U}$ showed the hydrophobic character. This result proved that hydrophobic isolate adhere to epithelial cell more than the hydrophilic did. Furthermore, isolate of $\mathrm{H} / \mathrm{U}$ wich grew diffusely in SSA medium possess higher number of adhesion compared to isolate of $\mathrm{H} / \mathrm{I}$ which grew compactly in SSA medium. According to Ljungh et al. (1985), the adhesion of $S$. aureus was mediated by the polysacharide capsule and also by protein receptor in the surface of mammary gland epithelial cell. The surface protein of S.aureus plays a role in adhesion process to the host protein like laminin and fibronectin which was present insurface extracellular matrix of epithelium and endothelium.

$\mathrm{H} / \mathrm{U}$ isolate grew diffusely in the SSA medium, but gave positive result on the hydrophobicity test. While, $\mathrm{H} / \mathrm{I}$ isolate grew compactly in the SSA medium, but gave negative result in the hydrophobicity test. This result did not correspond to the opinion of Ljungh et al. (1985) which stated that research using method of Hydrophobic Interaction Chromatography (HIC) and SAT would show that the strain that rich in protein A would have the hydrophobic surface but not as the autoaggregating character. This result deviation is affected by the different expression of capsule and protein either in the culture in SSA medium or in the reaction with ammonium sullfate. This is probably because $S$. aureus isolated from the dairy farm in Malang started to mutate. However, this hypothesis was still need to be reconfirmed. Teranishi et al. (1998) cited from Suarsana (2002) reported that Staphylococcus sp. which posssess protein A adhere in higher amount to the vero cell compared to the Staphylococcus $s p$. which doesn't possess protein A.

\section{CONCLUSION}

The adhesion ability of Staphylococcus aureus is affected by the ability to agglutinate erythrocyte, the hydrophobicity and the possession of protein $\mathrm{A}$.

\section{REFERENCES}

Abrar, M. 2001. Isolasi, Karakterisasai dan Aktivitas Biology Hemaglutinin Staphylococcus aureus dalam Proses Adhesi pada Permukaan Sel Epitel Ambing Sapi Perah. Disertasi Pasca Sarjana. Institut Pertanian Bogor. Bogor.

Edmondson PW, Andrews AH, Blowey RW, Boyd H, Eddy RG. 2004. Bovine Medicine Diseases and Husbandry of Cattle. $2^{\text {nd }}$ edition. Blackwell. Science

Forsum, U., A. Forsgren and E. Hjelm. 1972. Role of Protein A in the Serum-Soft Agar Technique. Infection and Immunity, Oct. 1972, p. 583-58

Freter, R. and G.W. Jones. 1983. Models for Studying the Role of Bacterial attachment in Virulence and Pathogenesis. Rev. Inf. Dis 5. pp 647-658

Green, M. and A. Bradely. 2004. Clinical ForumStaphylococcus aureus mastitis in cattle UK. Vet. 9:4

Han, Y., H. Ryul, P. Son-II, S.W. Kang, W.S. Jong and C.J. Youn. 2000. Capsular polysaccharide typing of domestic mastitiscausing Staphylococcus aureus strain and its potential exploration of bovine mastitis vaccine development. I. Capsular polysaccharide typing, isolation and purification of the strain. J. Vet. Sci. 1(1): 53-60

Kurl, D.N., S. Haataja and J. Finne. 1989. Hemaglutination cctivities in Streptococcus suis. Infect. Immun. 57: 384-389

Lehninger, A.L. 1990. Dasar-Dasar Biokimia. (Translated by Maggy Thenawijaya). Penerbit Erlangga. Jakarta. 313 pp.

Ljungh, A, S. Hjerten and T. Wadström. 1985. High surface hydrophobicity of autoaggregating Staphylococcus aureus strains isolated from human infections studied with the salt aggregation test. Infect. Immun. 47(2): 522-526.

Lowy, F. D. 1998. Staphylococcus aureus Infections. N. Engl. J. Ved.: 339 (27); 2025.

Mather, J.P. and P.E. Roberts. 1998. Introduction to Cell and Tissue Culture: Theory and Technique. Plenum Press. New York and 
London.

Miorner, H., P.A. Albertson, G. Kronvall. 1982. Isoelectric points and surface hydrophobic affinity partion in aqueous two-phase system. Infect and Immun. 36(1):227-235

Pelczar, M.J. and E.C.S. 2006. Dasar-dasar Mikrobiologi. (Translated by Hadioetomo, R.S) Penerbit Universitas Indonesia Press.Jakarta.

Rozgonyi, F., K.R. Szitha, S. Hjerten and T. Wadstrom. 1991. Standardization of salt aggregation test for reproducible determination of cell-surface hydrophobicity with special reference to Staphylococcus species. J. Appl. Bacteriol. 59: 451-457

Smith, T.H, 1984. The Biochemical challenge of microbial pathogenicity. J. Appl. Bact. 57:395-404.

Suarsana, N.I. 2002. Protein A : Peranannya dalam mekanisme infeksi. J. Vet. 20023 (1) :37-43

Subronto. 2003. Ilmu Penyakit Ternak I. Gadjah Mada University Press. Yogyakarta.

Sudarwanto, M. 1999. Usaha Peningkatan Produksi Susu Melalui Program Pengendalian Mastitis Subklinik. Orasi Ilmiah Guru Besar Tetap Ilmu Kesehatan Masyarakat Veteriner, Bogor, 22 Mei 1999. IPB Bogor.

Wahyuni, A.E.T.H., WI.T. Wibawan and M.H. Wibowo. 2005. Karakterisasi hemaglutinine Streptococcus agalactiae dan
Staphylococcus aureus penyebab mastitis subklinis pada sapi perah. J. Sain Vet. 23(2):79-86

Wahyuni, A.E.T.H. 1998. Peran hemaglutinine Streptococcus agalactiae dalam proses adhesi pada sel epitel sapi perah. Thesis Magister Sains. Program Pasca Sarjana-IPB.

Wibawan, I.W.T. H. Eva H, C.S. Damayanti dan Z. Kammaludin. 2005. Preparasi antiserum terhadap hemaglutinine Streptococcus agalactiae dan Staphylococcus aureus serta perannya sebagai anti adhesin dan opsonin. J. Vet. 6(2): 52-58

Wibawan, I.W.T., F.H. Pasaribu, I.H. Utama , A. Abdoelmawjood and Ch. Laemmler. 1999. The Role of hyaluronic acid capsular material of Streptococcus equi subsp. Zooepidemicus in mediating adherence to heLa cells and in resisting phagocytosis. Res. Vet. Sci. 67: 131-135

Wibawan, I.W.T., Ch. Laemmler, F.H. Pasaribu. 1992. Role of hydrophobic surface proteins in mediating adherence of group B Streptococci to epithelial cells. J. Gen. Microbiol. 138:1237-1242

Zarzosa, O.A., H.L. Ángeles, E.S. Cisneros, E.V. Gómez, L.L. Zárate and J.E.L. Meza. 2007. Antibacterial activity of thionin Thi2.1 from arabidopsis thaliana expressed by bovine endothelial cells against Staphylococcus aureus isolat from bovine mastitis. J. Vet.Microbial. Doi: 10.1016/j.vetmic. 